\title{
Moderating Effects of Shopping Values on the Antecedents of Unplanned Purchase Behavior: An Empirical Study of an International Travel Fair
}

\author{
Kuo-Hsien $\mathrm{Lu}^{1.2}$ \\ ${ }^{1}$ Department of Business Administration National Taipei University \\ ${ }^{2}$ Department of Hotel Management, Jinwen University of Science and Technology \\ E-Mail:wulu@just.edu.tw \\ Chih-Ming Wu \\ Department of Business Administration, National Taipei University \\ E-Mail: wcm@mail.ntpu.edu.tw
}

\begin{abstract}
This study investigated the influence of the antecedents of unplanned purchase behavior (service climate, travel attraction, in-store factors, and out-of-store factors) on the aforementioned behavior as well as the moderating effects of shopping values (hedonic and utilitarian shopping value) on unplanned purchase behavior. Questionnaires were distributed at an international travel fair and 443 valid samples collected. The results of the study are as follows: (1) Service climate, travel attraction, in-store factors, and out-of-store factors had positive influence on unplanned purchase behavior; (2) Hedonic shopping value moderated the effects of service climate, travel attraction, and in-store factors on unplanned purchase behavior; and (3) Utilitarian shopping value moderated the effects of service climate and in-store factors on unplanned purchase behavior. The results also revealed that the facility-related services provided by the international travel fair influenced visitors' unplanned purchase behavior. Sales were promoted at the fair site, and the "invisible" services provided by first-line service personnel affected the unplanned purchase behavior of visitors in terms of buying tourist accommodation. The results confirmed that shopping value influenced service climate, and that in-store factors affected unplanned purchase behavior. Regarding limitations, the current study only analyzed travel fair consumers from Taiwan. Future studies should include travel fair consumers from other countries and cultures to increase the robustness of the current study's results.
\end{abstract}

Keywords: Service climate, Travel attraction, In-Store factors, Out-of-Store factors, Hedonic shopping value, Utilitarian shopping value, Unplanned purchase behavior 


\section{INTRODUCTION}

With technological advancements, the daily consumption patterns of individuals have undergone rapid changes. The convenience of online shopping and online payments has changed people's consumption patterns, making unplanned purchase behaviors more common (Muruganantham \& Bhakat, 2013). Bhatti and Latif (2014) stated that unplanned purchase behaviors have created considerable opportunities for the industry and related stores, resulting in increased revenue because of unplanned purchases. Consequently, those in the industry have devoted substantial efforts to marketing and advertising to promote consumers' unplanned purchase behavior. This phenomenon has attracted interest from researchers. From a seller's' perspective, how to encourage consumers to buy more products or services to increase sales performance and revenue is crucial for business development. From a researcher's perspective, understanding the key factors that influence consumer's unplanned purchase behavior are the key research purposes.

Research has shown that service climate, the created atmosphere at stores, and external resources influence consumers' unplanned purchase behavior (Beatty \& Ferrel, 1998; Kalla \& Arora, 2011). For example, the arrangement and tidiness of boots or stands can make customers feel comfortable, leading to them staying in related areas longer and having an increased willingness to understand travel products, thereby increasing the probability of consumers making unplanned purchases. Convenient transportation to travel fairs brings more visitors and increases the probability of them engaging in unplanned purchase behaviors. Therefore, in addition to in-store and outof-store factors, service climate and travel attraction are considered antecedents of unplanned purchase behavior (Akram, Hui, Khan, Hashim, \& Rasheed, 2016).

Many studies related to unplanned purchase behavior have found that many consumers engage in such behaviors to satisfy their emotional needs at that moment; people engage in unplanned purchase behavior due to perceived hedonic shopping value. By contrast, consumers who have more consideration for utilitarian shopping value were less affected by their emotions or external environments in terms of their purchase behavior. This indicates that shopping values might influence consumers' unplanned purchase behavior (Hoch \& Loewenstein, 1991; Santini, Ladeira, Dalmoro, Falcão, \& Henz, 2016). The second motivation of this study was to investigate the moderating effects of different shopping values on the antecedents (service climate, travel attraction, in-store factors, and out-of-store factors) of unplanned purchase behavior.

According to statistical data provided by Taiwan's Executive Yuan, there was a $57.9 \%$ increase in domestic tourism and a 55.2\% increase in the total income from tourism between 2006 and 2017. As accommodation needs are the most basic needs for 
those engaging in tourism and travel, the hotel industry is strongly related to the tourism industry; accommodation businesses tend to participate in international travel fairs to increase publicity and provide promotional campaigns and policies to attract consumers and increase their willingness to purchase their accommodation products and services (Gilbride, Inman, \& Stilley, 2015). Therefore, the current research topic was focus on international travel fair.

The aim of this study was to consider service climate, travel attraction, in-store factors, and out-of-store factors as antecedents of unplanned purchase behavior and to investigate their effects on such behavior. Furthermore, the moderating effects of shopping values (hedonic and utilitarian shopping value) on such behavior were analyzed.

\section{LITERATURE REVIEW}

\section{Antecedents of Unplanned Purchase Behavior}

\section{Service climate}

Research has shown that the friendliness of service organization employees is a key factor that influences service quality and working attitude (Liao \& Chuang, 2007; Parasuraman, Zeithaml, \& Berry, 1985). In terms of working attitude, what is considered to be a "good" service mainly depends on the way how an employee delivers the service; therefore, how to build a good service climate is a crucial concern for related organizations. The concept of service climate was derived from organizational climate, which is defined as the service cognition shared by an organization's employees; this service cognition can help improve service performance and make consumers feel accounted (Schneider, White, \& Paul, 1998).

Recent research has mostly focused on service climate from the perspective of service providers. Schneider, Parkington, and Buxton (1980) found when organizational climate placed value on service quality, employees exhibited a friendly and positive service attitude. Research has also shown that service climate can increase service performance (Walumbwa, Peterson, Avolio, \& Hartnell, 2010) and service quality (Zhang, Liu, Wang, \& Shen, 2011) provided by employees. In this study, service climate was defined as employees' willingness to provide high-quality services, manifested in consumers' awareness of friendly service climate provided by first-line service personnel. It was hoped that such employees at stands at an internal travel fair could increase the probability of consumers engaging in unplanned purchase behavior.

\section{Travel attraction}

In the tour and travel industry, tourist attractions are the key to encouraging travelers to visit and stay at certain destinations (Borisoff \& Victor, 1989). Mill (1990) 
claimed that factors such as natural resources, culture, gourmet foods, and entertainment are the key factors that attract tourists to visit certain destinations (Victor, 1989; Wu \& Tian, 2017). Hu and Ritchie (1993) defined travel attraction as the overall satisfaction tourists have toward their travel destination. If certain attractions do not draw tourists, tourists are less willing to visit certain tourist spots, which can threaten the development of that tour industry; on the contrary, if the travel attractions or spots draw tourists, then tourists are willing to visit certain attractions or spots, thus enhancing the development of tourist spots (Swarbrooke, 2000). This also corresponding to the research result of Reitsamera, Brunner-Sperdinb, and Stokburger-Sauer (2016) that travel attraction is the key factor of tourists' travel destination choices.

This study was conducted at an international travel fair, and travel attraction was the key concept analyzed and was defined as a force that influences consumers at an international travel fair. When consumers consider international travel fairs to be attractive, those who did not previously plan to visit such fairs are more willing to do so. It was concluded that international travel fairs would attract consumers to go visit them and increase the likelihood of them engaging in unplanned purchase behavior.

\section{In-store and out-of-store factors}

Good in-store and out-of-store service environments can attract consumer and increase their willingness to make related purchases (Juhari, Ali, \& Khair, 2012). In terms of in-store factors, this study focused on store atmosphere. Details related to the interior design of the store-such as the brightness of lights, the music played, the merchandising, the smell, and the temperature-can create an attractive store atmosphere. An attractive store atmosphere can make consumers feel that the merchant takes the customers' enjoyment (i.e., in terms of visual, auditory, and olfactory senses) of the store shopping experience seriously; this could in turn enhance consumers' intention to remain at the store and increase their probability of purchasing the store merchandise (Akram et al., 2016; Hussain \& Ali, 2015). In terms of out-of-store factors, the researchers focused on the transportation-related convenience of the store and its exterior design. In the Internet age, consumers' frequency of engaging in online shopping behaviors has increased considerably. Brick-and-mortar retailers must rely on transportation-related convenience to attract consumers to shop at their stores; the more accessible a store is, the more willing are consumers to travel to that store (Chiang, 2018). In other words, the geographical location of a store is crucial (Behera \& Mishra, 2017). Kalla and Arora (2011) used consumers and stores to differentiate between instore and out-of-store factors; in-store factors include consumer's mental status, social status, and need for entertainment, whereas out-of-store factors include store environment, product arrangement, and discounts or promotions. In this study, in-store 
factors were defined as those stimulating consumers' senses, such as how closely product are placed together in a store, the brightness of a store, and the decoration of stands. Out of-store factors were defined as those influencing consumers' willingness to enter a store to shop, such as parking convenience, traffic congestion, and location of a travel fair. It was expected that in-store and out-of-store factors would influence consumers' perceptions of the shopping atmosphere at the travel fair and the probability of consumers engaging in unplanned purchase behavior. In-store and out-of-store factors were considered to be antecedents of unplanned purchase behavior.

\section{Unplanned Purchase Behavior}

Unplanned purchases occur when consumers are stimulated instantaneously by the shopping atmosphere and impulsively purchase products or services. Consequently, consumers can easily purchase products or services that they have no use for or that have a quality that is below their expectations; this type of high-risk shopping behavior can generate negative emotions such as regret, guilt, and anger with oneself (Rook, 1987). According to whether consumers have sufficient prior knowledge or generally behave sensibly, unplanned purchase behaviors can be divided into two dimensions that result in four types of buying behaviors: pure impulse, reminder impulse, suggestion impulse, and planned impulse purchases (Liao, Shen, \& Chu, 2008). Analyzing the types of unplanned purchase behaviors is beyond the scope of this study. In this study, unplanned purchase behavior was defined as consumers purchasing a product or service without thinking carefully while being affected by factors such as time pressure, special discounts, and lack of related information.

\section{Shopping Value}

The shopping process of consumers reflects their shopping value; they may make purchases to reach a shopping goal or purely to enjoy the pleasure of shopping (Babin, Darden, \& Griffin, 1994); therefore, researchers have considered that there are two basic shopping values: (1) utilitarian shopping, that is, shopping for a product or service to solve practical problems in life and (2) hedonic shopping, that is, shopping to satisfy particular emotions. When hedonic shoppers encounter a product or service that piques their interest, they engage in unplanned buying to satisfy their emotional needs (Pride \& Ferrell, 2000; Valence, Astous, \& Fortier, 1988).

According to the literature review, hedonic shopping value is based on a playful approach to fulfilling particular emotions; by contrast, utilitarian shopping value is based on rational cognition and completing shopping tasks related to planned purchase behaviors (Lee \& Wu, 2017; Ozkara, Ozmen, \& Kim, 2017). Therefore, in this study, hedonic shopping value was defined as a shopping behavior that consumers engage in 
to seek happiness and self-satisfaction, whereas utilitarian shopping value was defined as a shopping behavior that consumer engage in to fulfill practical needs. On the basis of these definitions, consumers with hedonic shopping value place more emphasis on satisfying personal emotions at a specific moment and are more likely to make unplanned purchases; by contrast, consumers with utilitarian shopping value are less likely to be influenced by their emotions or external factors when making purchases. It was expected that consumers who are more influenced by hedonic shopping value would be more likely to make unplanned purchases, and that consumers who are more influenced by utilitarian shopping value would be unlikely to make unplanned purchases.

\section{RESEARCH MODEL AND HYPOTHESES}

Servicescape theory is often used in marketing research. It assumes that consumers' perceptions are affected by the people, products, and things at shopping environments; these influence consumers' unplanned purchase behaviors owing to perceptions of a store and the related industry (Bitner, 1992; Berry \& Bendapudi, 2003). During the service process, if the service personnel show a positive service attitude and energy, consumers are subtlety influenced by this and feel pleasant and at ease, making them more willing to purchase a product or service from that store (Chuang \& Liao, 2010). Therefore, the following hypothesis was made.

H1: The antecedents of unplanned purchases have a positive effect on unplanned purchase behavior.

H1a: Service climate has a positive effect on unplanned purchase behavior.

Research has indicated that attraction has a positive effect on consumer satisfaction (Yu \& Goulden, 2006) and increases their willingness to revisit (Wang, Tsai, \& Chu, 2010). A relationship should exist between travel attraction and unplanned purchase behavior. Wang, Tsai, and Chu (2010) indicated that attraction can affect consumer's willingness to buy and purchase behavior; therefore, the following assumption was made.

H1b: Travel attraction has a positive effect on unplanned purchase behavior.

According to service scape theory, consumers evaluate the quality of a product or service based on outer decorations or how perfectly aligned products are. Consumers pick up on the positive emotions of sale personnel during the shopping process, thus triggering their desire to make unplanned purchases (Kalla \& Arora, 2011). Beatty and 
Ferrel (1998) posited that consumers are affected by in-store factors such as the product displayed, store atmosphere, personnel recommendations, shopping behaviors of other customers, and rushed shopping; these increase the probability of consumers making unplanned purchases. Thus, the following assumptions were made:

H1c: In-store factors have a positive effect on unplanned purchase behavior.

H1d: Out-of-store factors have a positive effect on unplanned purchase behavior.

According the theory on environmental psychology by Mehrabian and Russell, all environmental and human (in-store and out-of-store) factors can trigger emotional responses in consumers and related shopping behavior (Chen, Peng, \& Hung, 2015; Yasin, Sultan, Nazam, Akash, Hashim, \& Ahmad, 2019). Research has shown that consumers with hedonic shopping value are likely to be influenced by environmental factors that satisfy their desired shopping atmosphere at that moment, leading to them engaging in unplanned purchase behavior; consumers with utilitarian shopping value are likely to engage in such behaviors (Gholami, Dehbini, \& Shekari, 2016). Therefore, it was assumed that shopping values would have mediating effects on the antecedents of unplanned purchase behavior. The following hypotheses were made:

H2: Hedonic shopping value has a moderating effect on unplanned purchase behavior and its antecedents.

H2a: Hedonic shopping value has a moderating effect on service climate and unplanned purchase behavior.

H2b: Hedonic shopping value has a moderating effect on travel attraction and unplanned purchase behavior.

H2c: Hedonic shopping value has a moderating effect on in-store factors and unplanned purchase behavior.

H2d: Hedonic shopping value has a moderating effect on out-of-store factors and unplanned purchase behavior.

H3: Utilitarian shopping value has a moderating effect on unplanned purchase behavior and its antecedents.

H3a: Utilitarian shopping value has a moderating effect on service climate and unplanned purchase behavior.

H3b: Utilitarian shopping value has a moderating effect on travel attraction and unplanned purchase behavior.

H3c: Utilitarian shopping value has a moderating effect on in-store factors and unplanned purchase behavior.

H3d: Utilitarian shopping value has a moderating effect on out-of-store factors and 
unplanned purchase behavior.

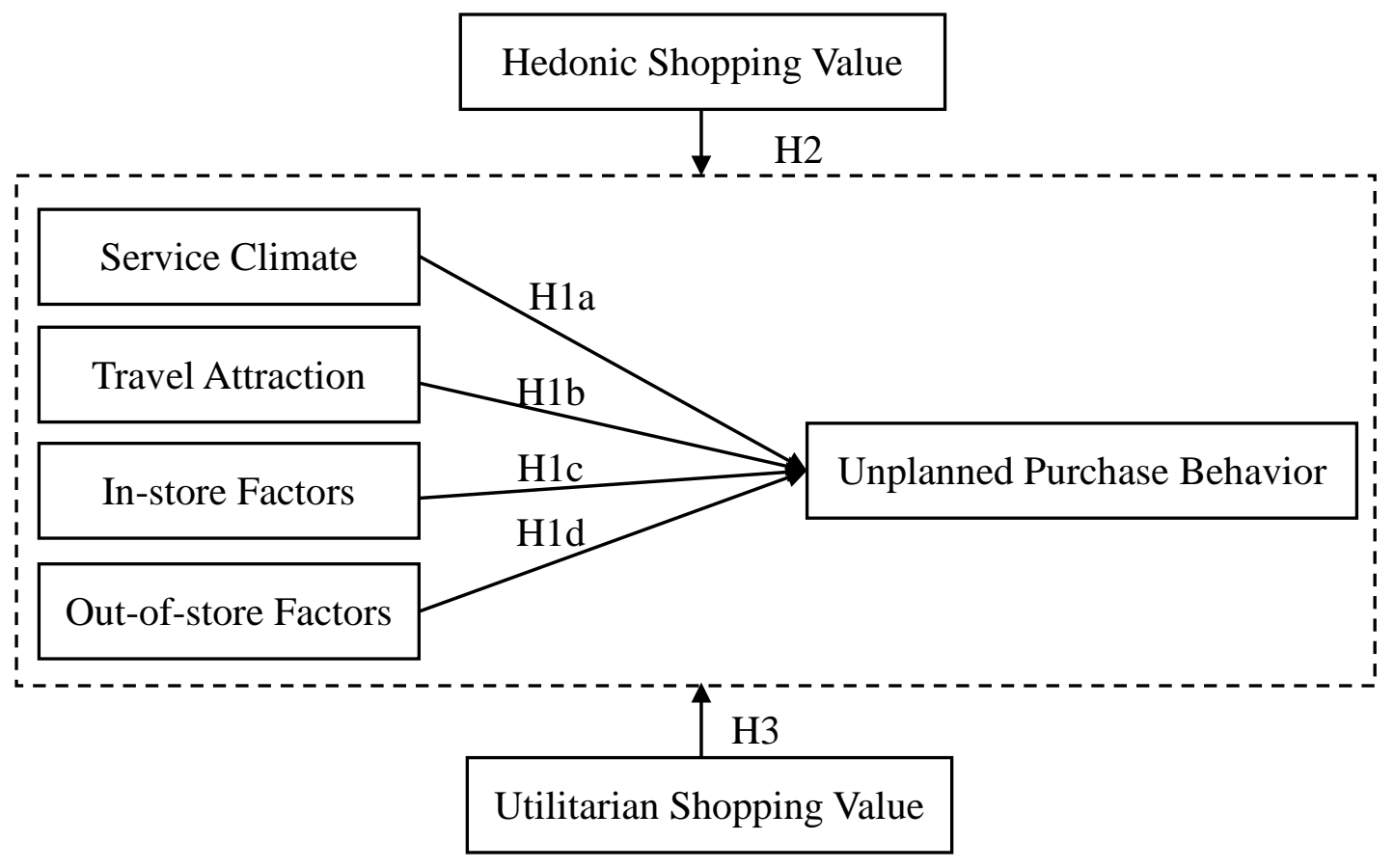

Figure 1. Research model

\section{METHODOLOGY}

\section{Measurement}

The Service Climate Questionnaire used in this study was modified from the original Service Climate Questionnaire developed by Schneider, White, and Paul (1998). Using the Service Climate Questionnaire devised by Schneider et al. as a reference point, the researchers further developed items of the questionnaire for the current study; the wording of items was later fine-tuned according to the themes and purpose of the current study. The modified questionnaire comprises two subdimensions: global service climate and customer orientation and feedback. This modified Service Climate Questionnaire contains a total of nine items and adopts a 5-point Likert scale scoring system, with options ranging from 1 (strongly disagree) to 5 (strongly agree); a higher score indicates a more positive service climate perceived by consumers.

The Travel Fair Attractiveness Questionnaire used in this study was modified from the Hotel Attractiveness Questionnaire designed by Chu and Choi (2000). Using the Hotel Attractiveness Questionnaire devised by Chu and Choi (2000) as a reference, the researchers developed items of the Travel Fair Attractiveness Questionnaire for the current study; the wording of items was later fine-tuned according to the themes and purpose of current study. The modified questionnaire comprises three subdimensions: 
service quality, value, and food and recreation. The constructed Travel Fair Attractiveness Questionnaire contains 14 items and has a 5-point Likert scale scoring system, with options ranging from 1 (strongly disagree) to 5 (strongly agree); a higher score indicates a higher level of travel fair attractiveness perceived by consumers.

The In-Store and Out-of-Store Factors Questionnaire used in this study was modified from the Merchandize Atmosphere Questionnaire developed by Turley and Milliman (2000). Specifically, the general interior variables were used as a reference point for in-store factors, whereas the external variables were used as a reference point for out-of-store factors; the wording of items was later fine-tuned according to the themes and purpose of current study. This In-Store and Out-of-Store Factors Questionnaire contains a total of nine items (i.e., five in-store factors items and four out-of-store factors items) and adopts a 5-point Likert scale scoring system, with options ranging from 1 (strongly disagree) to 5 (strongly agree).

The Repurchase Intension Questionnaire used in this study was modified from the Unplanned Purchasing Behavior Questionnaire developed by Rook and Fisher (1995). Using the Repurchase Intension Questionnaire devised by Rook and Fisher as a reference, the researchers developed items of the Repurchase Intension Questionnaire for the current study; the wording of items was later fine-tuned according to the themes and purpose of the current study. This Repurchase Intension Questionnaire contains nine items and has a 5-point Likert scale scoring system, with options ranging from 1 (strongly disagree) to 5 (strongly agree); a higher score indicates a higher possibility of consumers engaging in unplanned purchasing behavior.

\section{Sampling}

The research participants were visitors at an international travel fair; they were recruited at the fair site, and questionnaires were distributed to them. Of 450 returned questionnaires, a total of 443 valid samples were obtained. The demographic profile was obtained from the 443 valid samples of the participants and is shown in Table 1. 
Table 1. Demographic profile of the participants

\begin{tabular}{|c|c|c|c|}
\hline Variable & Category & Number & Percentage \\
\hline \multirow[t]{2}{*}{ Gender } & Male & 178 & 40.2 \\
\hline & Female & 265 & 59.8 \\
\hline \multirow[t]{6}{*}{ Age } & $\leqq 20$ years old & 57 & 12.9 \\
\hline & 21 30 years old & 154 & 34.8 \\
\hline & 31-40 years old & 66 & 14.9 \\
\hline & 41-50 years old & 70 & 15.8 \\
\hline & 51-60 years old & 56 & 12.6 \\
\hline & $\geqq$ 61years old & 40 & 9.0 \\
\hline \multirow[t]{3}{*}{ Eductaion } & $\leqq$ Senior & 74 & 16.7 \\
\hline & College & 314 & 70.9 \\
\hline & Graduate & 55 & 12.4 \\
\hline \multirow[t]{2}{*}{ Marriage } & Unmarried & 259 & 58.5 \\
\hline & Married & 184 & 41.5 \\
\hline \multirow[t]{4}{*}{ Residential area } & North area & 407 & 91.9 \\
\hline & Middle area & 14 & 3.2 \\
\hline & Southern area & 9 & 2.0 \\
\hline & East area & 13 & 2.9 \\
\hline \multirow{2}{*}{$\begin{array}{l}\text { Tourism exhibition purchase } \\
\text { accommodation products experience }\end{array}$} & Yes & 289 & 65.2 \\
\hline & No & 154 & 34.8 \\
\hline \multirow{2}{*}{$\begin{array}{l}\text { Purchased unexpected accommodation } \\
\text { products experience }\end{array}$} & Yes & 216 & 48.8 \\
\hline & No & 227 & 51.2 \\
\hline \multirow{5}{*}{$\begin{array}{l}\text { Purchase accommodation products } \\
\text { Amount }\end{array}$} & Less than NT3,000 & 106 & 23.9 \\
\hline & NT 3,000 to 6,000 & 126 & 28.4 \\
\hline & NT 6,001 to 10,000 & 92 & 20.8 \\
\hline & NT 10,001 to 15,000 & 60 & 13.5 \\
\hline & More than 15,001 & 59 & 13.2 \\
\hline \multirow[t]{2}{*}{ Service failure experience } & Yes & 117 & 26.4 \\
\hline & No & 326 & 73.6 \\
\hline \multirow[t]{2}{*}{ Complaint experience } & Yes & 107 & 24.2 \\
\hline & No & 336 & 75.8 \\
\hline
\end{tabular}

\section{Data Analyses}

Confirmatory factor analysis was used to examine the convergent validity and discriminant validity of each construct of this research. Cronbach's $\alpha$ was also used to explain the internal consistency of each construct. 
results are presented in Tables 2 and 3; the Cronbach's $\alpha$ value of each measure was between 0.756 and 0.955 , indicating that each variable had good reliability. The factor loadings of other variables and their corresponding latent variables were between 0.547 and 0.878 . The composite reliability (CR) values of service climate, travel attraction, in-store factors, out-of-store factors, hedonic shopping value, utilitarian shopping value, and unplanned purchase behavior were 0.943, 0.956, 0.931, 0.890,0.880, 766, and 0.949, respectively; the corresponding average variable extracted (AVE) values were $0.648,0.607,0.731,0.670,0.648,0.530$, and 0.676 , respectively. The CR value of each latent variable was higher than 0.7, and the AVE value was higher than 0.5, demonstrating good convergent validity (Fornell \& Larcker, 1981); the square roots of the AVE value were larger than the correlations of each two latent variables, which also indicated good discriminant validity.

Table 2. Reliability of the scales

\begin{tabular}{|c|c|c|c|c|c|}
\hline Construct & Items & $\begin{array}{l}\text { Standardized } \\
\text { Loading }\end{array}$ & Cronbach's $\alpha$ & CR & AVE \\
\hline Service & SC1 & 0.839 & 0.943 & 0.943 & 0.648 \\
\hline \multirow[t]{8}{*}{ Climate(SC) } & SC2 & 0.826 & & & \\
\hline & SC3 & 0.817 & & & \\
\hline & SC4 & 0.798 & & & \\
\hline & SC5 & 0.808 & & & \\
\hline & SC6 & 0.802 & & & \\
\hline & SC7 & 0.790 & & & \\
\hline & SC8 & 0.804 & & & \\
\hline & SC9 & 0.757 & & & \\
\hline Travel & TA1 & 0.794 & 0.955 & 0.956 & 0.607 \\
\hline \multirow[t]{11}{*}{ Attraction (TA) } & TA2 & 0.784 & & & \\
\hline & TA3 & 0.819 & & & \\
\hline & TA4 & 0.751 & & & \\
\hline & TA5 & 0.711 & & & \\
\hline & TA6 & 0.759 & & & \\
\hline & TA7 & 0.804 & & & \\
\hline & TA8 & 0.792 & & & \\
\hline & TA9 & 0.802 & & & \\
\hline & TA10 & 0.830 & & & \\
\hline & TA11 & 0.782 & & & \\
\hline & TA12 & 0.800 & & & \\
\hline
\end{tabular}




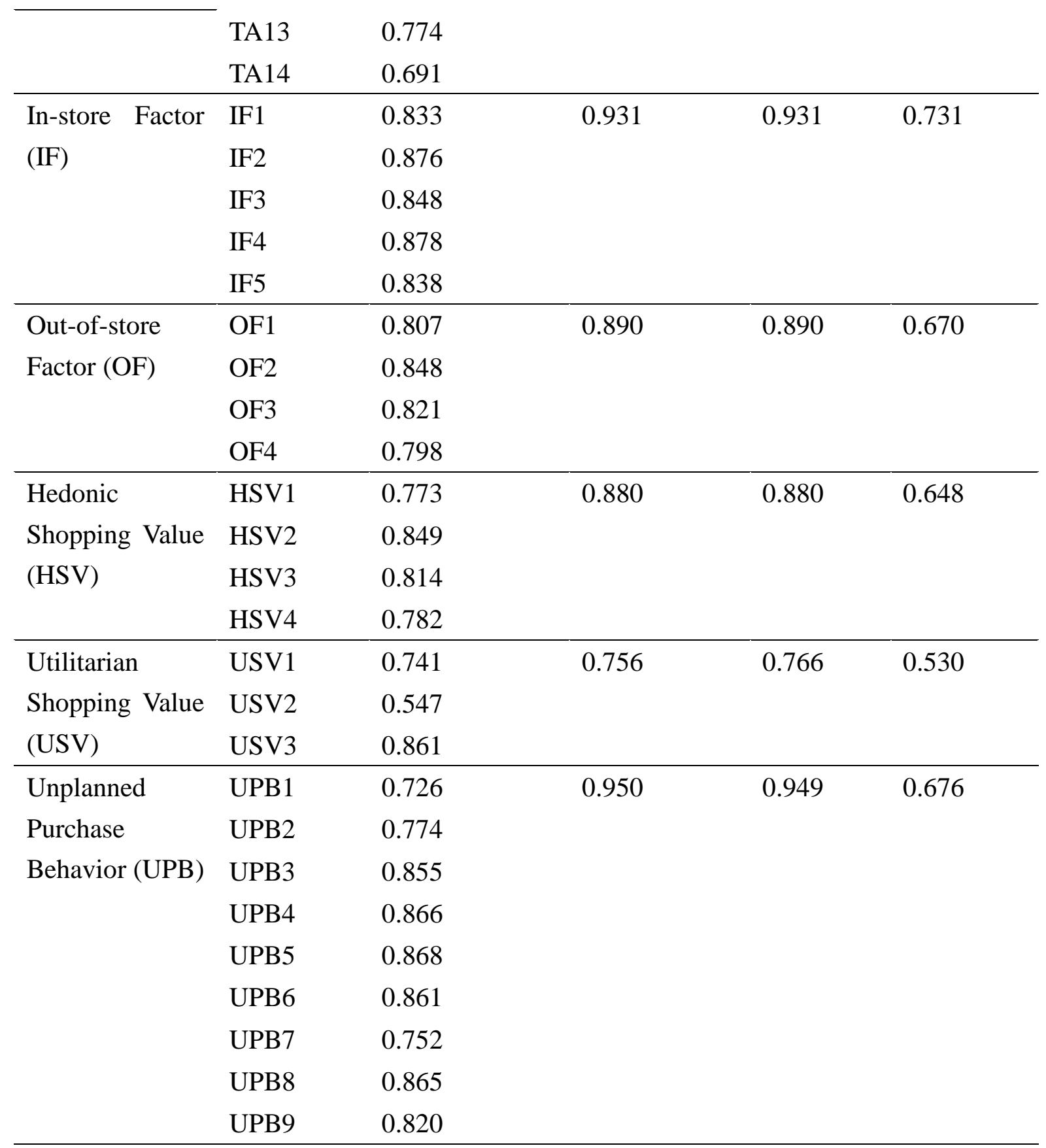


Table 3. Correlation matrix and discriminant validity assessment

\begin{tabular}{llccllll}
\hline \multicolumn{1}{c}{ SC } & TA & IF & OF & HSV & USV & UPB \\
\hline SC & 0.805 & & & & & & \\
\hline TA & $0.593^{* * *}$ & 0.779 & & & & & \\
\hline IF & $0.567^{* * *}$ & $0.605^{* * *}$ & 0.855 & & & & \\
\hline OF & $0.384^{* * *}$ & $0.484^{* * *}$ & $0.482^{* * *}$ & 0.819 & & & \\
\hline HSV & $0.461^{* * *}$ & $0.535^{* * *}$ & $0.455^{* * *}$ & $0.406^{* * *}$ & 0.805 & & \\
\hline USV & $0.207^{* * *}$ & $0.231^{* * *}$ & $0.155^{* * *}$ & $0.229^{* * *}$ & $0.208^{* * *}$ & 0.728 & \\
\hline UPB & $0.484^{* * *}$ & $0.546^{* * *}$ & $0.507^{* * *}$ & $0.473^{* * *}$ & $0.362^{* * *}$ & $0.163^{* * *}$ & 0.822 \\
\hline
\end{tabular}

Note: Diagonal elements are the square roots of AVE values. SC: service climate; TA: travel attraction; IF: in-store factor; OF: out-of-store factor; HSV: hedonic shopping value; USV: utilitarian shopping value; UPB: unplanned purchase behavior.

\section{RESULTS}

Structural equation modeling (SEM) was used. The goodness-of-fit index is shown in Table 4. All three constructs in the current study-service climate, travel attraction, and unplanned purchase behavior-had more than seven measurement indicators, and this may have resulted in a poor model fit. Hence, as suggested in related studies, the researchers resolved this problem by using the parcel method: the scores of various items were summed and averaged into a single measurement indicator to improve the overall fit of the model (Hall, Snell, \& Foust, 1999).

The overall model fit values for CMIN/DF, RMSEA, CFI, NFI, GFI, and AGFI were $1.955,0.046,0.982,0.963,0.938$, and 0.917 , respectively. The goodness-of-fit values in this study satisfied the criteria of related research (Kline, 2005).

Table 4. Fit indices of the structural model

\begin{tabular}{lllllll}
\hline Fit indices & $\chi 2 /$ d.f & RMSEA & CFI & NFI & GFI & AGFI \\
\hline Recommended values & $<3$ & $<0.08$ & $>0.90$ & $>0.90$ & $>0.80$ & $>0.80$ \\
Model values & 1.955 & .046 & .982 & .963 & .938 & .917 \\
\hline
\end{tabular}

The path coefficients of service climate, travel attraction, in-store factors, and outof-store factors to unplanned purchase behavior are shown in Table 5 and Figure 2. The results indicated that service climate, travel attraction, in-store factors, and out-of-store factors had positive effects on unplanned purchase behavior, implying that H1a (service climate has positive effect on unplanned purchase behavior), H1b (travel attraction has a positive effect on unplanned purchase behavior), H1c (in-store factors have a positive effect on unplanned purchase behavior), and H1d (out-of-store factors have a positive 
effect on unplanned purchase behavior) were all supported.

Table 5. Results of SEM analysis and structural coefficients

\begin{tabular}{lllll}
\hline & Non-std. coef. & SE & t-value & Std. coef. \\
\hline $\mathrm{SC} \rightarrow$ UPB & 0.150 & 0.060 & $2.518^{*}$ & 0.146 \\
\hline $\mathrm{TA} \rightarrow$ UPB & 0.278 & 0.068 & $4.104^{* * *}$ & 0.254 \\
\hline $\mathrm{IF} \rightarrow$ UPB & 0.141 & 0.055 & $2.579 *$ & 0.158 \\
\hline $\mathrm{OF} \rightarrow$ UPB & 0.250 & 0.056 & $4.446^{* * *}$ & 0.238 \\
\hline
\end{tabular}

Note: ${ }^{* *} p<0.01, * * * p<0.001$. SC: service climate; TA: travel attraction; IF: in-store factor; OF: out-of-store factor; UPB: unplanned purchase behavior.

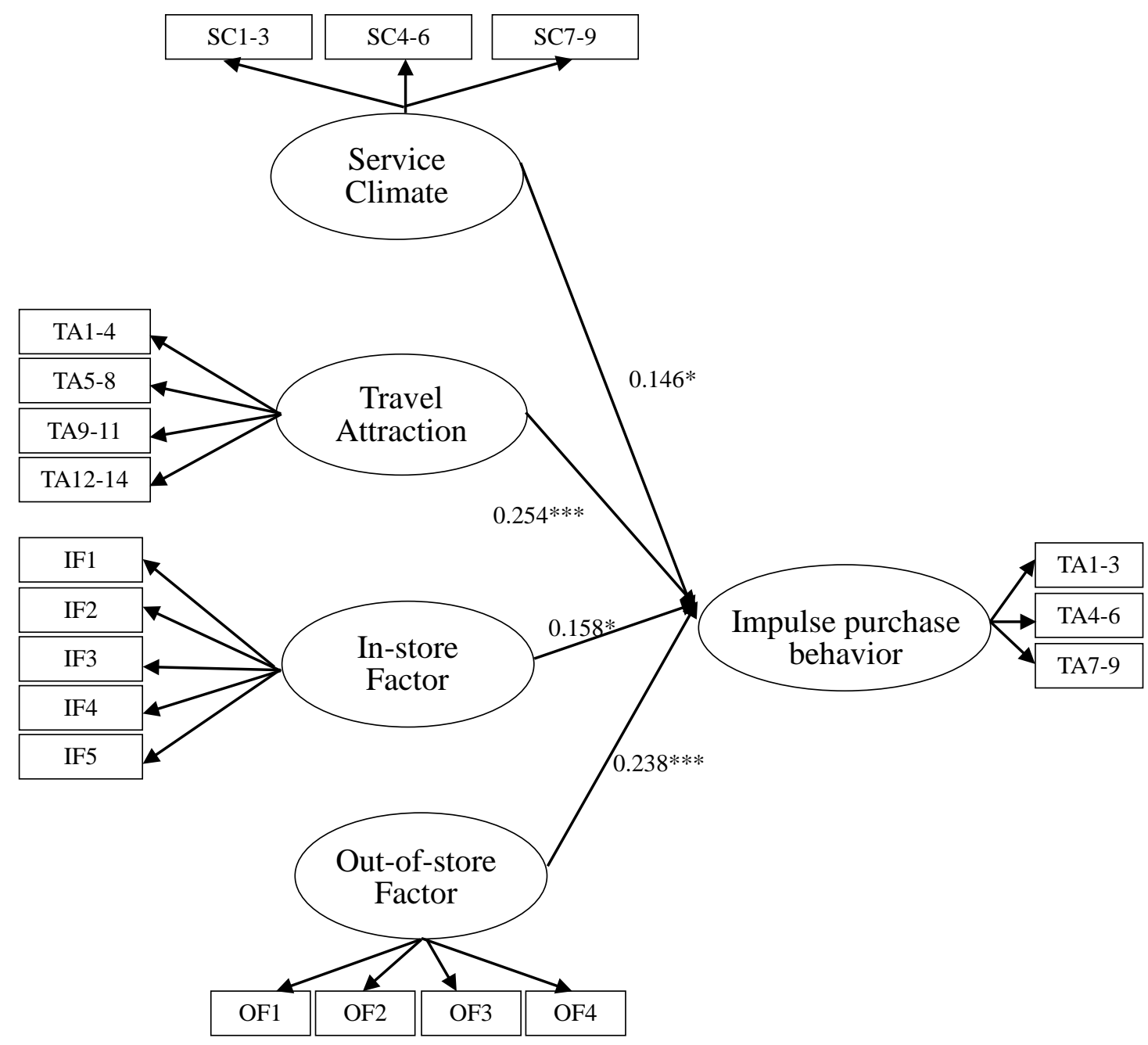

Figure 2. Results of SEM analysis

In accordance with suggestions in related studies, to avoid a severe multicollinearity problem in the regression analysis of moderating effects, precalculations of independent variables and moderators were required to minus their 
averages. Then, times each numbers as variables of interaction when conducting the regression analysis (Aiken \& West, 1991). The results of the moderating effects are shown in Table 6. Service climate and hedonic shopping value had a significant interaction effect (service climate $\times$ hedonic shopping value) on unplanned purchase behavior $(\beta=0.112, p<0.05)$, which supported $\mathrm{H} 2 \mathrm{a}$; travel attraction and hedonic shopping value had a significant interaction effect (travel attraction $\times$ hedonic shopping value) on unplanned purchase behavior ( $\beta=0.119, p<0.01$ ), which supported H2b; and in-store factors and hedonic shopping value had a significant interaction effect (instore factors $\times$ hedonic shopping value) on unplanned purchase behavior $(\beta=0.109, p$ $<0.05)$, which supported H2c. Out-of-store factors and hedonic shopping value did not have a significant interaction effect $(\beta=0.049, p>0.05)$ on unplanned purchase behavior, implying that H2d was not supported.

Regarding the moderating effects of utilitarian shopping value on the antecedents (service climate, travel attraction, in-store factors, and out-of-store factors) of unplanned purchase behavior, the results was revealed that service climate and utilitarian shopping value had a significant interaction effect (service climate $\times$ utilitarian shopping value) on unplanned purchase behavior $(\beta=0.230, p<0.001)$, which supported H3a; travel attraction and utilitarian shopping value did not have significant interaction effects $(\beta=0.094, p<0.01$ ) on unplanned purchase behavior, implying that H3b was not supported; in-store factors and utilitarian shopping value had a significant interaction effect (in-store factors $\times$ utilitarian shopping value) on unplanned purchase behavior ( $\beta=0.139, p<0.01$ ), which supported H3c; and out-ofstore factors and utilitarian shopping value did not have a significant interaction effect ( $\beta=0.041, p>0.05$ ) on unplanned purchase behavior, implying that H3d was not supported. 
Table 6. Results of moderating effects

\begin{tabular}{|c|c|c|c|c|}
\hline & Non-std. coef. & SE & t-value & Std. coef. \\
\hline $\mathrm{SC} \rightarrow \mathrm{UPB}$ & 0.362 & 0.051 & $7.164 * * *$ & 0.405 \\
\hline $\mathrm{HSV} \rightarrow \mathrm{UPB}$ & 0.172 & 0.053 & $3.266^{* *}$ & 0.177 \\
\hline $\mathrm{SC} \times \mathrm{HSV} \rightarrow \mathrm{UPB}$ & 0.141 & 0.056 & $2.530 *$ & 0.112 \\
\hline $\mathrm{TA} \rightarrow \mathrm{UPB}$ & 0.468 & 0.057 & $8.246 * * *$ & 0.499 \\
\hline $\mathrm{HSV} \rightarrow \mathrm{UPB}$ & 0.093 & 0.053 & 1.735 & 0.096 \\
\hline $\mathrm{TA} \times \mathrm{HSV} \rightarrow \mathrm{UPB}$ & 0.157 & 0.056 & $2.793 * *$ & 0.119 \\
\hline $\mathrm{IF} \rightarrow \mathrm{UPB}$ & 0.401 & 0.050 & $8.011 * * *$ & 0.453 \\
\hline $\mathrm{HSV} \rightarrow \mathrm{UPB}$ & 0.149 & 0.051 & $2.942 * *$ & 0.156 \\
\hline $\mathrm{IF} \times \mathrm{HSV} \rightarrow \mathrm{UPB}$ & 0.123 & 0.049 & $2.510 *$ & 0.109 \\
\hline $\mathrm{OF} \rightarrow \mathrm{UPB}$ & 0.386 & 0.053 & $7.265 * * *$ & 0.415 \\
\hline $\mathrm{HSV} \rightarrow \mathrm{UPB}$ & 0.185 & 0.051 & $3.626 * * *$ & 0.192 \\
\hline $\mathrm{OF} \times \mathrm{HSV} \rightarrow \mathrm{UPB}$ & 0.061 & 0.055 & 1.112 & 0.049 \\
\hline $\mathrm{SC} \rightarrow \mathrm{UPB}$ & 0.405 & 0.047 & $8.685 * * *$ & 0.454 \\
\hline $\mathrm{USV} \rightarrow \mathrm{UPB}$ & 0.026 & 0.038 & 0.675 & 0.033 \\
\hline $\mathrm{SC} \times \mathrm{USV} \rightarrow \mathrm{UPB}$ & 0.310 & 0.080 & $3.861 * * *$ & 0.230 \\
\hline $\mathrm{TA} \rightarrow \mathrm{UPB}$ & 0.495 & 0.053 & $9.355 * * *$ & 0.528 \\
\hline $\mathrm{USV} \rightarrow \mathrm{UPB}$ & 0.011 & 0.037 & 0.301 & 0.014 \\
\hline $\mathrm{TA} \times \mathrm{USV} \rightarrow \mathrm{UPB}$ & 0.123 & 0.074 & 1.664 & 0.094 \\
\hline $\mathrm{IF} \rightarrow \mathrm{UPB}$ & 0.447 & 0.046 & $9.651 * * *$ & 0.505 \\
\hline $\mathrm{USV} \rightarrow \mathrm{UPB}$ & 0.045 & 0.037 & 1.224 & 0.058 \\
\hline $\mathrm{IF} \times \mathrm{USV} \rightarrow \mathrm{UPB}$ & 0.154 & 0.059 & $2.626 * *$ & 0.139 \\
\hline $\mathrm{OF} \rightarrow \mathrm{UPB}$ & 0.455 & 0.052 & $8.738 * * *$ & 0.495 \\
\hline $\mathrm{USV} \rightarrow \mathrm{UPB}$ & 0.014 & 0.039 & 0.352 & 0.018 \\
\hline $\mathrm{OF} \times \mathrm{USV} \rightarrow \mathrm{UPB}$ & 0.047 & 0.060 & 0.784 & 0.041 \\
\hline
\end{tabular}

Note: ${ }^{*} p<0.05,{ }^{* *} p<0.01,{ }^{* * *} p<0.001$. SC: service climate; TA: travel attraction; IF: instore factor; OF: out-of-store factor; HSV: hedonic shopping value; USV: utilitarian shopping value; UPB: unplanned purchase behavior.

\section{DISCUSSION}

Service scape theory was used as the foundation of this research to evaluate the relationships of the antecedents of unplanned purchase behavior (service climate, travel attraction, in-store factors, and out-of-store factors) with unplanned purchase behavior, M-R theory for Environmental Psychology model was also applied to understand the moderating effects of shopping values on the antecedents of unplanned purchase behavior to unplanned purchase behavior. Twelve hypotheses were established, and 
only H2d, H3b, and H3d were not supported by the results. Suggestions and management meanings are discussed in the following section.

First, the results demonstrated that service climate had a positive effect on unplanned purchase behavior. Although the promoted products at the international travel fair were related to accommodation, visitors were supposed to choose their accommodation according to their needs; however, at the fair site, first-line service personnel at each stand built a shopping atmosphere to create a shared perception of service climate while they explained their accommodation products. In a positive service climate, visitors were more willing to make unplanned purchases while they had pleasant conversations with the first-line service personnel, who were attempting to raise their sales performance, and purchased their products. Therefore, the creation of a positive service climate increased the ability of staff to provide professional explanations of products and services at the fair stands.

Second, travel attraction had a significantly positive effect on unplanned purchase behavior at the international travel fair. Most accommodation stands attempted to draw the attention of visitors and fulfill their expectations; preference for or premium combination packages with substantial bonuses were usually provided to encourage visitors to make unplanned purchases at the fair. Thus, special promotions and discounts should be provided at such fairs to encourage visitors to purchase accommodation products.

In-store factors had a significantly positive effect on the unplanned purchase behavior of visitors to the international travel fair. This indicated that by providing a comfortable shopping environment, visitors would be immersed in and enjoy the lively shopping atmosphere; this would increase the desires of consumers to make purchases, which corresponds to the previous research finding that consumers prefer tidy and bright shopping environments (Chang, Eckman, \& Yan, 2011).

Out-of-store factors had a significantly positive effect on unplanned purchase behavior at the international travel fair. The purpose of holding an international travel fair was to promote the development of the travel industry and provide a platform to allow each machinist to gather and give consumers the opportunity to compare the offers provided by multiple stands so that such stands could increase their sales performance. According to these findings, an international travel fair must attract a considerable number of people to increase purchase intention; the convenience of the fair site and traffic considerations directly influence the numbers of visitors. In general, having more visitors results in vendors having better sale performance; this can result in an increase in unplanned purchase behavior. It is suggested that organizations holding international travel fairs should consider the convenience of access to the fair site and traffic considerations to increase visitors' willingness to visit the fair. 
Hedonic shopping value had significant moderating effects on service climate and unplanned purchase behavior, travel attraction and unplanned purchase behavior, and in-store factors and unplanned purchase behavior. However, hedonic shopping value did not have a significant moderating effect on out-of-store factors and unplanned purchase behavior. Consumers with hedonic shopping value have more consideration for the emotional aspects of shopping; for example, if service personnel are gentle and polite, have a good attitude, and provide a comfortable shopping atmosphere, hedonic shopping value would influence the perceptions of consumers in making purchases. Therefore, hedonic shopping value had significantly moderating effects on service climate and unplanned purchase behavior, travel attraction and unplanned purchase behavior, and in-store factors and unplanned purchase behavior. Hedonic shopping value did not have a significant moderating effect on out-of-store factors and unplanned purchase behavior, possibly because the questionnaires for out-of-store factors mainly focused on location and traffic convenience, which may have made it more difficult to induce positive perceptions that would lead to an increase in unplanned purchase behavior.

Finally, the results revealed that utilitarian shopping value had significant moderating effects on service climate and unplanned purchase behavior and in-store factors and unplanned purchase behavior. However, utilitarian shopping value did not have significant moderating effects on travel attraction and unplanned purchase behavior and out-of-store factors and unplanned purchase behavior. Thus, it was concluded that a detailed explanation of the services provided by first-line service personnel can help consumers with utilitarian shopping value better understand related products and remind them of their inclination to only buy what they need. The appropriate arrangement of accommodation products on fair stands and the creation of a comfortable environment would attract visitors to visit the stands and learn about the accommodation products provided and promoted; this could lead to an increase in unplanned purchase behavior.

The overall atmosphere and the formation of a positive service climate should be the main focuses to increase the probability of visitors making unplanned purchases; this could increase the sales performance of those in the industry at future international travel fairs.

This study had several limitations. In this section, limitations and corresponding suggestions for improvement are discussed. First, this study only analyzed consumers from Taipei City, Taiwan. To confirm the robustness of the study results, future researchers should test this research framework using consumers from other countries and other cultures. Second, most consumers who visited the international travel fair, that is the event explored in this study, had a low to medium economic status. Thus, the 
current study results may not be generalizable to consumers with a high economic status. Future researchers should replicate this study using consumers of different economic statuses. Third, in the current study, the researchers used a cross-sectional research design to collect data from the participants. In other words, all data from the current study were collected at a single time point; this could have weakened the robustness of causality between the variables. To enhance such robustness, researchers could adopt a longitudinal research design and collect data at least two time points. Finally, the researchers did not analyze the types and prices of merchandise actually purchased by the travel fair consumers. An examination of these aspects may reveal the key factors related to the impulsive shopping behaviors of travel fair consumers.

\section{REFERENCES}

Aiken, L. S., \& West, S. G. (1991). Multiple Regression: Testing and interpreting interactions, Newbury Park, CA: Sage.

Akram, U., Hui, P., Khan, M. K., Hashim, M., \& Rasheed, S. (2016). Impact of store atmosphere on impulse buying behaviour: Moderating effect of demographic variables. International Journal of u-and e-Service, Science and Technology, 9(7), 43-60. https://doi.org/10.14257/ijunesst.2016.9.7.05

Babin, B. J., Darden, W. R., \& Griffin, M. (1994). Work and/or fun: Measuring hedonic and utilitarian shopping value. Journal of Consumer Research, 20(4), 644-656. https://doi.org/10.1086/209376

Beatty, S. E., \& Ferrell, M. E. (1998). Impulse buying: Modeling its precursors. Journal of Retailing, 74(2), 169-191. https://doi.org/10.1016/s0022-4359(98)90009-4

Behera, M. P., \& Mishra, V. (2017). Impact of store location and layout on consumer purchase behavior in organized retail. Anvesha, 10(1), 10-21.

Berry, L. L., \& Bendapudi, N. (2003). Clueing in customers. Harvard Business Review, 81(2), 100-106.

Bhatti, K. L., \& Latif, S. (2014). The impact of visual merchandising on consumer PLE Regression: Testing and interpreting interactions impulse buying behaviour. Eurasian Journal of Business and Management, 2(1), 24-35.

Bitner, M. J. (1992). Servicescapes: The impact of physical surrounding on customer and employees. Journal of Marketing, 56(2), 57-71.

https://doi.org/10.2307/1252042

Borisoff, D., \& Victor, D. A. (1989). Conflict management: A communication skills approach, New York: Prentice-Hall, Inc.

Chang, H. J., Eckman, M., \& Yan, R.N. (2011). Application of the stimulus-organismresponse model to the retail environment: The role of hedonic motivation in impulse buying behavior. The International Review of Retail, Distribution and 
Consumer Research, 21(3), 233-249.

https://doi.org/10.1111/j.1744-6570.2009.01165.x

Chen, A., Peng, N., \& Hung, K. P. (2015). The effects of luxury restaurant environments on diners' emotions and loyalty: Incorporating diner expectations into an extended Mehrabian-Russell model. International Journal of Contemporary Hospitality Management, 27(2), 236-260. https://doi.org/10.1108/ijchm-07-2013-0280

Chiang, C. F. (2018). Influences of price, service convenience, and social service scape on post-purchase process of capsule hotels. Asia Pacific Journal of Tourism Research, 23(4), 373-384. https://doi.org/10.1080/10941665.2018.1444649

Chu, R. K., \& Choi, T. (2000). An importance-performance analysis of hotel selection factors in the Hong Kong hotel industry: A comparison of business and leisure travellers. Tourism management, 21(4), 363-377. http://dx.doi.org/10.1016/s02615177(99)00070-9

Chuang, C. H., \& Liao, H. (2010). Strategic human resource management in service context: Taking care of business by taking care of employees and customers. Personnel Psychology, 63(1), 153-196.

https://doi.org/10.1111/j.1744-6570.2009.01165.x

Fornell, C. R., \& Larcker, D. F. (1981). Evaluating structural equation models with unobservable variables and measurement error. Journal of Marketing Research, 18(1), 39-51. https://doi.org/10.2307/3151312

Gholami, S., Dehbini, N., \& Shekari, A. (2016). The impact of store atmosphere on hedonic and utilitarian shopping values, customer satisfaction and customer purchase intention. Journal of Current Research in Science, Supplement, 1, 305311. https://doi.org/10.13140/RG.2.1.3250.6001

Gilbride, T., Inman, J. J., \& Stilley, K. M. (2015). The role of within-trip dynamics in unplanned versus planned purchase behavior. Journal of Marketing, 79, 57-73. https://doi.org/10.1509/jm.13.0286

Hall, R. J., Snell, A. F., \& Foust, M. S. (1999). Item parceling strategies in SEM: Investigating the subtle effects of unmodeled secondary constructs, Organizational Research Methods, 2(3), 233-256. https://doi.org/10.1177/109442819923002

Hoch, S. J., \& Loewenstein, G. F. (1991). Time -inconsistent preferences and consumer self-control. Journal of Consumer Research, 17, 492-507.

https://doi.org/10.1086/208573

Hu, Y., \& Ritchie, J.R.B. (1993). Measuring destination attractiveness: A contextual approach. Journal of Travel Research, 32(2), 2-34.

https://doi.org/10.1177/004728759303200204

Hussain, R., \& Ali, M. (2015). Effect of store atmosphere on consumer purchase intention. International Journal of Marketing Studies, 7(2), 35-43. 
https://doi.org/10.5539/ijms.v7n2p35

Juhari, N. H., Ali, H. M., \& Khair, N. (2012). The shopping mall services cape affects customer satisfaction. 3rd International Conference on Business and Economic Research (3rd ICBER 2012).

Kalla, S. M., \& Arora, A. P. (2011). Impulse buying: A literature review. Global Business Review, 12(1), 145-157. https://doi.org/10.1177/097215091001200109

Kline, R. B. (2005). Principles and practice of structural equation modeling (2 ed.), New York: Guilford.

Lee, C. H., \& Wu, J. J. (2017). Consumer online flow experience: The relationship between utilitarian and hedonic value, satisfaction and unplanned purchase. Industrial Management \& Data Systems, 117(10), 2452-2467.

https://doi.org/10.1108/imds-11-2016-0500

Liao, H., \& Chuang, A. (2007). Transforming service employees and climate: A multilevel multi-source examination of transformational leadership in building longterm service relationships. Journal of Applied Psychology, 92, 1006-1019. https://doi.org/10.1037/0021-9010.92.4.1006

Liao, S. L., Shen, Y. C., \& Chu, C. H. (2008). The decision characteristics of reminder impulse buying triggered by promotion, product and personality factors. Chiao Da Management Review, 28(2), 131-162.

Mill, R. C. (1990). Tourism: The international business, Englewood Cliffs, NJ: Prentice Hall.

Muruganantham, G., \& Bhakat, R. S. (2013). A review of impulse buying behavior. International Journal of Marketing Studies, 5(3), 149-160.

https://doi.org/10.5539/ijms.v5n3p149

Ozkara, B. Y., Ozmen, M., \& Kim, J. W. (2017). Examining the effect of flow experience on online purchase: A novel approach to the flow theory based on hedonic and utilitarian value. Journal of Retailing and Consumer Services, 37, 119-131. https://doi.org/10.1016/j.jretconser.2017.04.001

Parasuraman, A., Zeithaml, V. A., \& Berry, L. L. (1985). A conceptual model of service quality and its implications for future research. Journal of Marketing, 49(4), 4150. https://doi.org/10.1177/002224298504900403

Pride, W. M., \& Ferrell, O. C. (2000). Marketing: Concept and Strategies, Boston, MA: Houghton Mifflin.

Reitsamera, B. F., Brunner-Sperdinb, A., \& Stokburger-Sauer, N.E. (2016). Destination attractiveness and destination attachment: The mediating role of tourists' attitude. Tourism Management Perspectives, 19, 93-101.

https://doi.org/10.1016/j.tmp.2016.05.003

Rook, D.W. (1987). The buying impulse. Journal of Consumer Research, 14(9), 189- 
199. http://dx.doi.org/10.1086/209105

Rook, D. W., \& Fisher, R. J. (1995). Normative influences on impulsive buying behavior. Journal of consumer research, 22(3), 305-313. https://doi.org/10.1086/209452

Santini, F. O., Ladeira, W. J., Dalmoro, M., Falcão, C. A., \& Henz, M. M. (2016). Purchase a new car: The effect of impulsiveness in the Brazilian market. The Academy of Marketing Science, Springer, 271-275.

https://doi.org/10.1007/978-3-319-19428-8_69

Schneider, B. (1990). Organizational Climate and Culture, San Francisco: Jossey-Bass.

Schneider, B., Parkington, J. J., \& Buxton, V. M. (1980). Employee and customer perceptions of service in banks. Administrative Science Quarterly, 25(2), 252-267. https://doi.org/10.2307/2392454

Schneider, B., White, S. S., \& Paul, M. C. (1998). Linking service climate and customer perceptions of service quality: Test of a causal model. Journal of Applied Psychology, 83(1), 50-163. https://doi.org/10.1037//0021-9010.83.2.150

Swarbrooke, J. (2000). The Development and Management of Visitor Attraction, Oxford: Butterworth-Heinemann.

Turley, L. W., \& Milliman, R. E. (2000). Atmospheric effects on shopping behavior: A review of the experimental evidence. Journal of business research, 49(2), 193-211. https://doi.org/10.1016/S0148-2963(99)00010-7

Valence, G. A., Astous, A., \& Fortier, L. (1988). Compulsive buying: Concept and measurement. Journal of Consumer Policy, 11, 419-433.

https://doi.org/10.1007/bf00411854

Victor, T. C. (1989). Marketing implications for attractions. Tourism Management, 10(3), 229-232. https://doi.org/10.1016/0261-5177(89)90080-0

Walumbwa, F. O., Peterson, S. J., Avolio, B. J., \& Hartnell, C. A. (2010). An investigation of the relationships among leader and follower psychological capital, service climate, and job performance. Personnel Psychology, 63, 937-963. https://doi.org/10.1111/j.1744-6570.2010.01193.x

Wang, S., Tsai, C. Y., \& Chu, Y. C. (2010). Tourist behavior in Hakka cultural parks. African Journal of Business Management, 4(14), 2952-2961. https://doi.org/10.5897/AJBM

Wu, S. I., \& Tian, M. L. (2017). Impact of consumers' preference for cultural and creative parks on the attitude behavior model. International Journal of Business and Management, 12(8), 201-218. https://doi.org/10.5539/ijbm.v12n8p201

Yasin, M. A., Sultan, F., Nazam, M., Akash, R. S. I., Hashim, M., \& Ahmad, J. (2019). Designing the Super Store atmosphere with non-visual stimulants: effects on shoppers' purchase and emotional behavior. Dilemas Contemporáneos: Educación, Política y Valore, 6, 1-28. 
Yu, L., \& Goulden, M. (2006). A comparative analysis of international tourists' satisfaction in Mongolia. Tourism Management, 27(6), 1331-1342. https://doi.org/10.1016/j.tourman.2005.06.003

Zhang, R.-Y., Liu, X.-M., Wang, H.-Z., \& Shen, L. (2011). Service climate and employee service performance: Exploring the moderating role of job stress and organizational identification. The Service Industries Journal, 31, 2355-2372. https://doi.org/10.1080/02642069.2010.503873

Dr. Kuo-Hsien Lu (Corresponding author) is the doctoral candidate of Department of Business Administration in National Taipei University, and is the assistant professor of hotel management department in JinWen University of Science \& Technology. He primarily interests in the information management, marketing, and hospitality and tourism management.

Dr. Chih-Ming Wu is an associate professor of the Department of the Business Administration, National Taipei University. His research focuses are mainly on supply chain management, and customer relationship management. His research papers have been published at journals of Information Management, Journal of Business Administration, and Journal of Global Business and Technology. 